\title{
PENERAPAN SISTEM PERTANGGUNGJAWABAN PIDANA BAGI \\ LEMBAGA PERBANKAN DITINJAU DARI SISTEM PERTANGGUNGJAWABAN PIDANA KORPORASI
}

\author{
Kristian \\ Universitas Surya Kencana \\ yehezkiel.kristian90@gmail.com \\ DOI : https://doi.org/10.29313/shjih.v17i2.4550
}

\begin{abstract}
ABSTRAK
Keberadaan lembaga perbankan memberikan dampak yang positif, tetapi juga keberadaan lembaga perbankan dapat berdampak negatif dimana lembaga perbankan sebagai suatu korporasi dapat menjadi pelaku tindak pidana yang merugikan masyarakat luas namun seringkali tidak tersentuh oleh hukum. Hasil penelitian menunjukan bahwa sistem pertanggungjawaban pidana korporasi telah dilegitimasi dan dijustifikasi oleh beberapa doktrin atau teori yakni: identification theory, strict liability theory, vicarious liability doctrine, the corporate culture model atau company culture theory, doctrin of aggregation, dan reactive corporate fault. Jika dikaitkan dengan pokok permasalahan yang diteliti, sistem pertanggungjawaban pidana korporasi sebagaimana dilegitimasi dan dijustifikasi oleh berbagai teori tersebut dapat diterapkan terhadap lembaga perbankan. Dengan demikian, bank dipandang dapat melakukan tindak pidana dan menanggung pertanggungjawaban pidana. Namun demikian, sistem pertanggungjawaban pidana bagi lembaga perbankan belum dapat diterapkan karena undang-undang perbankan masih didominasi oleh asas "societas delinquere non potest" dan terbentur dengan asas legalitas.
\end{abstract}

Kata Kunci: Sistem Pertanggungjawaban Pidana, Bank, Sistem Pertanggungjawaban Pidana Korporasi.

\section{ABSTRACT}

The existence of a banking institution has a positive impact, but also the existence of a banking institution can have a negative impact where the banking institution as a corporation can be a criminal offense that is detrimental to the wider community but is often not touched by law. The results show that the corporate criminal liability system has been legitimized and justified by several doctrines or theories namely: identification theory, strict liability theory, vicarious liability doctrine, the corporate culture model or company culture theory, doctrine of aggregation, and reactive corporate fault. If it is related to the subject matter examined, the corporate criminal 
liability system as legitimized and justified by various theories can be applied to banking institutions. Thus, banks are considered to be able to commit criminal acts and bear criminal liability. However, the criminal liability system for banking institutions cannot be implemented because the banking law is still dominated by the principle of "societas delinquere non potest" and collided with the principle of legality.

Keywords: Criminal Liability System, Bank, Corporate Criminal Liability System.

\section{A. PENDAHULUAN}

\section{Latar Belakang Masalah}

Perbankan mempunyai fungsi utama sebagai lembaga intermediasi, yaitu lembaga yang menghimpun dana dari masyarakat dan menyalurkannya secara efektif dan efisien pada sektor-sektor riil untuk meningkatkan pemerataan pembangunan dan hasil-hasilnya, meningkatkan pertumbuhan ekonomi dan menjaga stabilitas perekonomian nasional, peningkatan taraf hidup rakyat banyak (meningkatkan kesejahteraan masyarakat), mewujudkan masyarakat Indonesia yang adil dan makmur dan menciptakan keadilan sosial bagi seluruh rakyat Indonesia. Keberadaan korporasi dalam hal ini adalah lembaga perbankan harus diwaspadai karena tidak selamanya keberadaan lembaga perbankan sebagai suatu korporasi memberikan dampak yang positif. Keberadaan lembaga perbankan juga dapat berdampak negatif dimana korporasi (lembaga perbankan) dapat menjadi pelaku tindak pidana dan melakukan berbagai tindak pidana yang merugikan masyarakat luas namun seringkali tidak tersentuh oleh hukum.

Terkait dengan hal ini, Johannes Ibrahim dan Yohanes Hermanto Sirait dalam bukunya yang berjudul "Kejahatan Transfer Dana (Evolusi Dan Modus Kejahatan Melalui Sarana Lembaga Keuangan Bank)" menyatakan bahwa lingkup pelaku dan tindak pidana perbankan dapat dilakukan oleh perorangan maupun badan hukum (korporasi). ${ }^{1}$ Selanjutnya, Johannes Ibrahim dan Yohanes Hermanto Sirait menjelaskan bahwa beragam modus kejahatan di bidang

${ }^{1}$ Johannes Ibrahim dan Yohanes Hermanto Sirait, Kejahatan Transfer Dana (Evolusi Dan Modus Kejahatan Melalui Sarana Lembaga Keuangan Bank), PT. Sinar Grafika, Jakarta, 2018., hlm. 129. 
perbankan semakin banyak terjadi. ${ }^{2}$ Dahulu, Bank yang selalu menjadi sasaran kejahatan perampokan, kini tidak lagi selalu dipandang sebagai korban kejahatan. Kini, kejahatan juga bisa dilakukan oleh bank sebagai korporasi. ${ }^{3}$ Bank yang awalanya merupakan lembaga intermediasi ternyata banyak dikeluhkan oleh nasabah oleh karena beberapa kasus yang menjerat para petinggi bank. Tindak kejahatan yang dilakukan bank dapat berupa penipuan dan penggerusan dana nasabah. ${ }^{4}$

Tindak pidana perbankan merupakan bagian atau salah satu bentuk dari tindak pidana atau kejahatan kerah putih (white collar crime), tindak pidana atau kejahatan yang bersifat terorganisasi (organized crimes), bersifat sistemik dan luar biasa (systemic and extra ordinary crimes). Tindak pidana perbankan juga merupakan tindak pidana dengan dimensi-dimensi kejahatan yang baru (new dimention of crime). Perlu pula disadari bahwa tindak pidana ini dapat berjalan karena keterlibatan dari pelaku usaha bank sendiri, baik dari kalangan bawah hingga direksi bahkan pemegang saham dari bank.

Maraknya tindak pidana perbankan yang dilakukan oleh bank salah satunya disinyalir karena keinginan bank sebagai suatu korporasi untuk terus meningkatkan keuntungan yang diperolehnya. Keinginan ini telah membuat bank mengabaikan kebijakan-kebijakan yang ditentukan oleh undang-undang. Selain itu, maraknya tindak pidana perbankan yang dilakukan oleh bank disebabkan karena bank memiliki kekuasaan yang besar dalam menjalankan aktivitas dan bisnisnya sehingga ia sering kali melakukan aktivitas atau bisnis yang bertentangan dengan hukum yang berlaku. Hal ini diperparah dengan kondisi bank sebagai suatu korporasi dapat dengan mudah menghilangkan bukti-bukti dari tindak pidana yang telah dilakukannya.

Fungsi yang begitu penting dari lembaga perbankan dan maraknya tindak pidana perbankan yang terjadi memunculkan sebuah pertanyaan bagi penulis,

\footnotetext{
${ }^{2}$ Ibid.

${ }^{3}$ Ibid., hlm. 139.

${ }^{4}$ Ibid.
} 
mungkinkah sistem pertanggungjawaban pidana korporasi diterapkan terhadap bank? Dengan konstruksi yang demikian maka bank sebagai suatu korporasi dinilai dapat melakukan tindak pidana dan dapat mempertanggungjawabkan perbuatannya secara pidana pula. Hal ini menjadi penting untuk kita pikirkan mengingat dalam perkembangan terkini, dalam berbagai tindak pidana khusus, korporasi telah dijadikan subjek tindak pidana yang penerapannya telah dilegitimasi dan dijustifikasi oleh beberapa doktrin atau teori diantaranya: identification theory (teori identifikasi), strict liability theory (teori pertanggungjawaban ketat menurut undang-undang), vicarious liability doctrine (teori atau doktrin pertanggungjawaban pengganti), the corporate culture model atau company culture theory (teori budaya korporasi), doctrin of aggregation (doktrin agregasi) dan reactive corporate fault. Pertanyaannya adalah, bagaimana penerapan sistem pertanggungjawaban pidana bagi lembaga perbankan jika ditinjau dari berbagai teori atau doktrin yang melegitimasi sistem pertanggungjawaban pidana korporasi tersebut? Apakah Undang-Undang Republik Indonesia Nomor 10 Tahun 1998 Tentang Perubahan atas Undang-Undang Republik Indonesia Nomor 7 Tahun 1992 Tentang Perbankan telah mengakui korporasi (dalam hal ini bank) sebagai subjek tindak pidana?

Terkait dengan pertanyaan tersebut, tidak dapat dipungkiri bahwa dalam praktiknya sekarang, masih banyak penegak hukum dan ahli hukum (khususnya ahli hukum perbankan) yang belum menerima bank sebagai suatu korporasi dapat dimintakan pertanggungjawaban secara pidana. Hal ini salah satunya didasarkan pada argumentasi bahwa hanya manusia alamiah yang dapat melakukan tindak pidana karena hanya manusia alamiahlah yang mempunyai kesalahan atau sikap batin jahat, pemidanaan terhadap bank dapat menimbulkan dampak sistemik terhadap bank-bank lainnya bahkan akan mengganggu sistem perbankan nasional dan pemidanaan terhadap lembaga perbankan dapat menimpa pada orang yang tidak bersalah atau menimbulkan masalah-masalah baru. Hal ini diperparah dengan praktik penegakan hukum di Indonesia yang cenderung menjatuhkan pidana kepada pengurus bank saja (manusia alamiah) sebagai pelaku tindak pidana sedangkan bank sebagai korporasinya tidak dimintakan pertanggungjawaban apapun. 


\section{Identifikasi Masalah}

Artikel ini akan membahas bagaimana mengukur dan menentukan kesalahan atau sikap batin jahat (mens rea) dari korporasi? kapan dan dalam hal bagaimana suatu tindak pidana yang dilakukan oleh organ atau pengurus dapat dikatakan sebagai tindak pidana yang dilakukan oleh korporasi dan hal-hal apa yang menjadi dasar untuk menerapkan sistem pertanggungjawaban pidana bagi sebuah bank sebagai suatu korporasi?

\section{Metode Penelitian}

Metode penelitian yang digunakan dalam penelitian ini adalah metode penelitian hukum normatif dengan melakukan studi kepustakaan. Adapun studi kepustakaan ini dilakukan dengan cara menganalisa isi (content analysis), yaitu sebuah teknik untuk menganalisa tulisan atau dokumen dengan cara mengidentifikasi secara sistematik ciri atau karakter dan pesan atau maksud yang terkandung dalam suatu tulisan atau suatu dokumen. ${ }^{5}$ Tipologi penelitian ini yaitu penelitian deskriptif (analistis), dimana penelitian ini bertujuan untuk menggambarkan secara tepat sifat daripada suatu keadaan atau gejala. ${ }^{6}$ Dari sudut penerapannya maka penelitian ini adalah penelitian murni ( atau disebut juga dengan penelitian dasar atau pure research), yaitu penelitian yang bertujuan untuk pengembangan ilmu atau teori. ${ }^{7}$

\section{B. PEMBAHASAN}

Untuk menjawab beberapa pertanyaan berkaitan dengan penerapan sistem pertanggungjawaban pidana bagi lembaga perbankan, secara teoritik terdapat beberapa doktrin atau teori yang membenarkan atau menjustifikasi korporasi sebagai subjek tindak pidana dimana korporasi dinilai dapat melakukan tindak

${ }^{5}$ Sri Mamudji, et.al., Metode Penulisan dan Penelitian Hukum, Penerbit PT. Alumni, 2005, hlm. 29-30.

${ }^{6}$ Ibid., hlm. 4.

${ }^{7}$ Ibid., hlm. 5. 
pidana dan dapat dimintakan pertanggungjawaban secara pidana. Doktrin-doktrin atau teori-teori tersebut dapat diuraikan secara singkat sebagai berikut:

\section{a. Identification Theory (Teori Identifikasi)}

Doktrin pertama yang membenarkan atau menjustifikasi penerapan sistem pertanggungjawaban pidana korporasi adalah "identification theory" atau dikenal juga dengan "direct liability doctrine". Doktrin pertanggungjawaban pidana langsung atau doktrin identifikasi adalah salah satu teori yang digunakan sebagai teori pembenar bagi penerapan sistem pertanggungjawaban pidana korporasi meskipun korporasi bukanlah sesuatu yang dapat berdiri sendiri.

Suatu korporasi dinilai dapat melakukan tindak pidana secara langsung melalui "pejabat senior" (senior officer) dan perbuatan dari "pejabat senior" (senior officer) ini diidentifikasi sebagai perbuatan perusahaan atau korporasi itu sendiri. Dengan demikian maka perbuatan "pejabat senior" (senior officer) dipandang atau dapat dikategorikan sebagai perbuatan dari korporasi. Dalam teori, ini agar suatu korporasi dapat dibebani pertanggungjawaban pidana maka orang yang melakukan tindak pidana tersebut harus dapat didentifikasi terlebih dahulu. Pertanggungjawaban pidana baru dapat benar-benar dibebankan kepada korporasi apabila perbuatan pidana atau tindak pidana yang dilakukan tersebut benar-benar dilakukan oleh orang yang merupakan "pejabat senior" (senior officer) sekaligus "directing mind" dari korporasi tersebut. Hal senada juga dikemukakan oleh Richard Card, yang menyatakan bahwa: "the acts and state of mind of the person are the acts and state of mind of the corporation" (tindakan atau kehendak direktur merupakan tindakan dan kehendak dari korporasi). ${ }^{8}$

\footnotetext{
${ }^{8}$ Muladi, Penerapan Pertanggungjawaban Pidana Korporasi Dalam Hukum Pidana, Bahan Kuliah Kejahatan Korporasi, Universitas Diponegoro (UNDIP)., hlm. 21.
} 


\section{b. Strict Liability (Teori Pertanggungjawaban Ketat Menurut Undang- Undang)}

Doktrin kedua yang menjustifikasi atau membenarkan penerapan sistem pertanggungjawaban pidana korporasi adalah strict liability atau pertanggungjawaban ketat menurut undang-undang. Doktrin atau teori ini juga sering disebut dengan teori pertanggungjawaban mutlak atau pertanggungjawaban tanpa kesalahan atau disebut dengan "no-fault liability" atau " liability without fault". Dalam prinsip ini, pertanggungjawaban pidana dapat dimintakan tanpa keharusan untuk membuktikan adanya kesalahan atau sikap batin jahat dari pelaku tindak pidana.

Strict liability menurut Russel Heaton diartikan sebagai suatu pertanggungjawaban pidana dengan tidak mensyaratkan adanya kesalahan pada diri pelaku terhadap satu atau lebih dari actus reus. ${ }^{9}$ Jadi dalam hal ini, strict liability merupakan pertanggungjawaban tanpa kesalahan (liability without fault). Hamzah Hatrik mendefinisikan bahwa strict liability adalah pertanggungjawaban tanpa kesalahan (liability without fault), yang dalam hal ini si pembuat sudah dapat dipidana jika ia telah melakukan perbuatan yang dilarang sebagaimana telah dirumuskan dalam undang-undang, tanpa melihat lebih jauh sikap batin si pembuat. ${ }^{10}$ Disamping itu, Hanafi dalam bukunya yang berjudul "Strict Liability dan Vicarious Liability dalam Hukum Pidana" menegaskan bahwa dalam perbuatan pidana yang bersifat strict liability hanya dibutuhkan dugaan atau pengetahuan dari pelaku (terdakwa). Dugaan dan pengetahuan dari pelaku sudah cukup menuntut pertanggungjawaban pidana dari padanya. Jadi, dalam teori ini tidak dipersoalkan adanya mens rea (kesalahan) karena unsur pokok strict liability adalah actus reus

\footnotetext{
${ }^{9}$ Russel Heaton, Criminal Law Textbook, Oxford University Press, London, 2006, hlm. 403.

${ }^{10}$ Hamzah Hatrik, Asas Pertanggungjwaban Korporasi Dalam Hukum Pidana (Strict Liability dan Vicarious Liability), PT. Raja Grafindo Persada, Jakarta, 1996, hlm. 110.
} 
(perbuatan) sehingga yang harus dibuktikan adalah actus reus (perbuatan), bukan mens rea (kesalahan)nya. ${ }^{11}$

Mengenai pertangunggjawaban ketat menurut undang-undang (strict liability) ini dalam kaitannya dengan korporasi (dalam hal ini adalah lembaga perbankan), korporasi dapat dibebani pertanggunggjawaban atas tindak pidana tertentu yang tidak harus dibuktikan unsur kesalahannya (mens rea). Dalam hal ini, manakala lembaga perbankan (yang diwakili oleh organ atau pengurusnya) melakukan tindak pidana dan memenuhi rumusan delik dari tindak pidana tersebut sebagaimana telah dirumuskan dalam undang-undang maka pertanggungjawaban pidana dapat dibebankan kepada lembaga perbankan tersebut tanpa keharusan untuk membuktikan kesalahan atau sikap batin jahatnya.

\section{c. Vicarious Liability Doctrine (Teori Pertanggungjawaban Pengganti)}

Doktrin ketiga yang membenarkan atau menjustifikasi penerapan sistem pertanggungjawaban pidana bagi suatu korporasi adalah vicarious liability doctrine. Pada dasarnya, doktrin vicarious liability didasarkan pada prinsip “employment principle”. Yang dimaksud dengan prinsip employment principle dalam hal ini bahwa majikan (employer) adalah penanggungjawab utama dari perbuatan para buruhnya atau karyawannya. Jadi dalam hal ini terlihat prinsip "the servant's act is the master act in law" atau yang dikenal juga dengan prinsip "the agency principle" yang berbunyi "the company is liable for the wrongful acts of all its employees". ${ }^{12}$

Mengenai employment principle ini, Peter Gillies mengemukakan beberapa pendapat dalam kaitannya dengan vicarious liability, yaitu sebagai berikut. ${ }^{13}$

\footnotetext{
${ }^{11}$ Hanafi, Strict Liability dan Vicarious Liability dalam Hukum Pidana, Lembaga Penelitian, Universitas Islam Indonesia, Yogyakarta, 1997. hlm. 15.

${ }^{12}$ Barda Nawawi Arief, Perbandingan Hukum Pidana, Raja Grafindo Persada, Jakarta, 2010, hlm. 249.

${ }^{13}$ Ibid., hlm. 236.
} 
a. Suatu perusahaan atau korporasi (seperti halnya manusia sebagai pelaku atau pengusaha) dapat bertanggung jawab secara pengganti untuk perbuatan yang dilakukan oleh karyawan atau agennya. Pertanggungjawaban demikian hanya timbul untuk delik atau tindak pidana yang mampu dilakukan secara vicarious.

b. Dalam hubunganya dengan "employment principle", tindak pidana ini sebagian besar atau seluruhnya merupakan "summary offences" yang berkaitan dengan peraturan perdagangan.

c. Kedudukan majikan atau agen dalam ruang lingkup pekerjaannya, tidaklah relevan menurut doktrin ini. Tidaklah penting bahwa majikan, baik sebagai korporasi maupun secara alami, tidak mengarahkan atau memberi petunjuk atau perintah pada karyawan untuk melakukan pelanggaran terhadap hukum pidana. (Bahkan, dalam beberapa kasus, vicarious liability dikenakan terhadap majikan walaupun karyawan melakukan perbuatan yang bertentangan dengan instruksi, berdasarkan alasan bahwa karyawan dipandang telah melakukan perbuatan itu dalam ruang lingkup pekerjaannya). Oleh karena itu, apabila perusahaan terlibat, pertanggungjawaban muncul sekalipun perbuatan itu dilakukan tanpa menunjuk pada pejabat senior di dalam perusahaan.

Menurut asas repondeat superior, di mana ada hubungan antara master dan servant atau antara principal dan agent, berlaku pendapat dari Maxim yang berbunyi qui facit per alium facit per se. ${ }^{14}$ Menurut pendapat Maxim tersebut, seorang yang berbuat melalui orang lain dianggap dirinya sendiri yang melakukan perbuatan itu. Oleh karena itu, ajaran vicarious liability juga disebut sebagai ajaran respondent superior ${ }^{15}$ Berdasarkan doktrin pertanggungjawaban pengganti ini, seseorang dapat dipertanggungjawabkan atas perbuatan atau kesalahan atau perbuatan dan kesalahan orang lain. Pertanggungjawaban seperti ini hampir seluruhnya diterapkan pada tindak pidana yang secara tegas diatur dalam undang-

\footnotetext{
${ }^{14}$ Ibid.

${ }^{15}$ Ibid.
} 
undang. Dengan kata lain, tidak semua delik dapat dilakukan secara vicarious. Dikaitkan dengan pertanggungjawaban pidana korporasi, menurut V.S. Khanna dalam tulisannya yang berjudul "Corporate Liability Standars: When Should Corporation Be Criminality Liabel?" dikemukakan bahwa terdapat 3 (tiga) syarat yang harus dipenuhi untuk adanya pertanggungjawaban pidana korporasi secara vicarious, yaitu; agen melakukan suatu kejahatan; kejahatan yang dilakukan itu masih dalam ruang lingkup pekerjaannya; dan kejahatan itu dilakukan dengan tujuan untuk menguntungkan atau memberikan manfaat bagi korporasi. ${ }^{16}$

Teori ini juga hanya dibatasi pada keadaan tertentu di mana majikan (dalam konteks ini korporasi) hanya bertangungjawab atas perbuatan salah pekerja yang masih berada dalam ruang lingkup pekerjaannya. ${ }^{17}$ Rasionalitas penerapan teori ini adalah karena majikan (dalam konteks ini korporasi) memiliki kontrol dan kekuasaan atas mereka dan keuntungan yang mereka peroleh secara langsung dimiliki oleh majikan (korporasi) ${ }^{18}$ Jadi dalam hal ini, doktrin pertanggungjawaban pengganti hanya dapat diterapkan apabila benar-benar dapat dibuktikan bahwa ada hubungan atasan dan bawahan antara majikan (korporasi) dengan buruh atau karyawan yang melakukan tindak pidana. Oleh sebab itu, harus diperhatikan benarbenar apakah hubungan antara korporasi dengan organ-organnya cukup layak untuk dapat membebankan pertanggungjawaban pidana kepada majikan (dalam hal ini korporasi) atas tindak pidana yang dilakukan oleh organ-organ atau penguruspengurusnya tersebut. Selain itu juga harus dipastikan apakah tindak pidana yang dilakukan oleh buruh atau karyawannya tersebut berada dalam kapasitas lingkup pekerjaannya atau tidak.

\footnotetext{
${ }^{16}$ V.S. Khanna, Corporate Liability Standars: When Should Corporation Be Criminality Liabel?, American Criminal Law Review, 2000, hlm. 1242-1243.

${ }_{17}$ C.M.V. Clarkson, Understanding Criminal Law,Second Edition, Sweet \& Maxwell, London, 1998, hlm. 44.

${ }^{18}$ Ibid., hlm. 45.
} 
Menurut Marcus Flatcher, dalam perkara pidana terdapat 2 (dua) syarat penting yang harus dipenuhi untuk dapat menerapkan pertanggungjawaban pidana dengan pertanggungjawaban pengganti, syarat tersebut adalah sebagai berikut: ${ }^{19}$

1. Harus terdapat suatu hubungan pekerjaan, seperti hubungan antara majikan dan pegawai atau pekerja;

2. Perbuatan pidana atau tindak pidana yang dilakukan oleh pegawai atau pekerja tersebut berkaitan atau masih berada dalam ruang lingkup pekerjaannya.

E.M. Meijers menyatakan bahwa suatu perbuatan yang dilakukan oleh organ atau pengurus dapat dipertanggungjawabkan kepada korporasi apabila memenuhi syarat-syarat sebagai berikut: ${ }^{20}$

1. Perbuatan-perbuatan organ atau pengurus yang dilakukan dalam batas-batas kewenangannya;

2. Perbuatan organ atau pengurus di luar wewenangnya, tetapi kemudian disahkan oleh organ yang lebih tinggi;

3. Perbuatan organ atau pengurus itu menguntungkan atau memberikan manfaat bagi badan hukum yang bersangkutan;

4. Tindakan-tindakan organ atau pengurus yang merupakan perbuatan melanggar hukum dalam batas wewenangnya; dan

5. Tindakan organ atau pengurus merupakan perbuatan melanggar hukum dalam batas-batas wewenangnya, tetapi ada kesalahan pribadi dari organ atau pengurus tersebut sehingga badan hukum tetap terikat.

Berikutnya, menurut hemat penulis, suatu tindak pidana yang dilakukan oleh organ atau pengurus dapat dikategorikan sebagai tindak pidana yang dilakukan oleh korporasi (dan oleh karenanya korporasi harus dimintakan pertanggungjawaban secara pidana) manakala terpenuhi beberapa persyaratan sebagai berikut:

${ }^{19}$ Hanafi, Op.Cit. hlm. 34.

${ }^{20}$ Kristian, Sistem Pertanggungjawaban Pidana Korporasi Ditinjau Dari Berbagai Konvensi Internasional, PT. Refika Aditama, 2017., hlm. 56. 
a. Tindak pidana dilakukan oleh personil pengendali korporasi (sebagai senior officer atau directing mind);

b. Tindak pidana dilakukan karena diperintahkan oleh personil pengendali korporasi (adanya pendelegasian oleh pihak yang sah);

c. Tindak pidana dilakukan oleh agen atau organ atas nama korporasi atau dilakukan dalam lingkup pekerjaannya;

d. Tindak pidana dilakukan dalam rangka pemenuhan maksud dan tujuan korporasi;

e. Tindak pidana dilakukan melalui agen yang berhubungan erat dengan korporasi;

f. Tindak pidana dilakukan sesuai dengan tugas dan fungsi pelaku atau pemberi perintah;

g. Tindak pidana yang dilakukan oleh atau hasil kesepakatan dari sekumpulan orang secara kolektif yang ada dalam korporasi yang bersangkutan;

h. Korporasi tidak membentuk sebuah sistem, prosedur, disiplin internal atau pengawasan dan budaya (yang terdapat dalam korporasi) yang dapat mencegah dan menindak dilakukannya tindak pidana;

i. Korporasi gagal menindak pelanggaran (tindak pidana) yang terjadi dalam korporasi tersebut;

j. Tindak pidana dilakukan dengan maksud untuk memberikan manfaat atau keuntungan bagi Korporasi.

Dalam kaitannya dengan penerapan sistem pertanggungjawaban pidana korporasi bagi bank, penulis menilai sistem pertanggungjawaban pidana korporasi dapat diterapkan terhadap lembaga perbankan dengan menggunakan teori ini. Dalam hal ini, bank dapat dimintakan pertanggungjawaban pidana manakala tindak pidana dilakukan oleh organ atau pengurus atau karyawan bank dalam lingkup pekerjaannya, tindak pidana yang dilakukan tersebut memberikan manfaat atau keuntungan bagi bank yang bersangkutan, dan berbagai syarat lainnya sebagaimana disyaratkan oleh doktrin pertanggungjawaban pengganti (vicarious liability doctrine). 


\section{d. The Corporate Culture Model atau Company Culture Theory (Teori Budaya Korporasi)}

Doktrin keempat yang membenarkan atau menjustifikasi sistem pertanggungjawaban pidana korporasi adalah doktrin the corporate culture model. Menurut doktrin atau teori the corporate culture model atau sering pula disebut dengan company culture theory, korporasi dapat dipertanggungjawabkan dilihat dari prosedur, sistem bekerjanya, atau budaya yang terdapat dalam korporasi tersebut (the procedures, operating systems, or culture of a company). Oleh karena itu, teori budaya korporasi ini sering juga disebut teori atau model sistem atau model organisasi (organisational or systems model). ${ }^{21}$

Pendekatan jenis ini digunakan oleh Australia. Istilah corporate culture dapat di lihat dalam Australian Criminal Code Act 1995 (undang-undang hukum pidana Australia) yang menjelaskan bahwa sistem pertanggungjawaban pidana bagi korporasi dapat diterapkan dengan memperhatikan beberapa hal sebagai berikut: "an attitude, policy, rule, course of conduct or practice existing within the body corporate generally or in the part of the body corporate in which the relevant activities take place" (suatu bentuk sikap, kebijakan, aturan, rangkaian perbuatan atau praktek yang pada umumnya terdapat dalam tubuh atau organisasi korporasi atau dalam bagian tubuh atau bagian korporasi dimana kegiatan-kegiatan terkait berlangsung). ${ }^{22}$

Menurut teori atau doktrin ini, suatu korporasi yang dalam hal ini adalah lembaga perbankan dapat dimintakan pertanggungjawaban secara pidana apabila bank tidak membentuk kebijakan, aturan, kode etik perilaku, budaya kerja dan hal-

${ }^{21}$ Barda Nawawi Arief, Bunga Rampai Kebijakan Hukum Pidana, Bandung, Citra Aditya Bakti, 2008, hlm. 251.

${ }^{22}$ Christopher M. Little \& Natasha Savoline, Corporate Criminal Liability in Canada: The Criminalization of Occupational Health \& Safety Offences, Filion Wakely Thorup Angeletti (Management Labour Lawyers), diakses dari: www.filion.on.ca/pdf/CML\%202003\%20Paper.pdf., hlm. 11 . 
hal lainnya yang dapat mencegah dilakukannya tindak pidana oleh para organ, pengurus atau karyawan bank.

Sebaliknya, apabila bank telah membentuk berbagai hal tersebut di atas di mana hal-hal itu dapat mencegah dan meminimalisasi dilakukannya tindak pidana oleh organ atau pengurus atau karyawan bank, lembaga perbankan tidak dapat dimintakan pertanggungjawaban secara pidana karena lembaga perbankan tersebut telah membentuk budaya korporasi yang baik. Oleh karena itu, penting sekali bagi bank untuk menerapkan prinsip good corporate governance, prinsip manajemen risiko dan prinsip kehati-hatian perbankan (prudential banking).

\section{e. Doctrin Of Aggregation (Doktrin Agregasi)}

Doktrin kelima yang membenarkan atau menjustifikasi penerapan sistem pertanggungjawaban pidana bagi suatu korporasi adalah doctrin of aggregation. Doctrin of aggregation atau dalam bahasa Indonesia dapat disebut dengan "doktrin agregasi" merupakan sebuah doktrin yang memperhatikan kesalahan sejumlah orang secara kolektif yaitu kesalahan dari orang-orang yang bertindak untuk dan atas nama suatu korporasi atau orang-orang yang bertindak untuk kepentingan korporasi yang bersangkutan. ${ }^{23}$ Menurut doktrin atau teori ini, apabila terdapat sekelompok orang yang melakukan tindak pidana namun orang tersebut bertindak untuk dan atas nama suatu korporasi atau untuk kepentingan suatu korporasi atau dalam rangka memberikan manfaat atau keuntungan bagi suatu korporasi maka korporasi tersebut dapat dibebankan pertanggungjawaban secara pidana. Dalam hal ini, baik orang-orang yang bersangkutan ataupun korporasi dapat dibebankan pertanggungjawaban secara pidana. Menurut doktrin ini, semua perbuatan dan unsur mental atau sikap batin jahat atau kesalahan (mens rea) dari kumpulam orang tersebut dianggap sebagai dan dilakukan oleh suatu korporasi sehingga korporasi tersebut layak dibebankan pertanggungjawaban secara pidana.

Menurut hemat penulis, teori ini tidak berbeda dengan teori pertanggungjawaban pengganti (vicarious liability) sebagaimana telah dijelaskan

${ }^{23}$ Rise Karmilia, Pengaturan Pertanggungjawaban Pidana Korporasi Pada Ketentuan Pidana Di Luar KUHP, Thesis, Universitas Sumatera Utara (USU), 2009., hlm. 77. 
pada bagian sebelumnya. Namun perbedaannya hanya terletak pada jumlah atau kuantitas dari orang yang melakukan tindak pidananya. Dalam vicarious liability atau doktrin pertanggungjawaban pengganti, tidak disyaratkan harus ada "sekumpulan orang" atau "sekelompok orang" yang bertindak untuk dan atas nama atau bagi kepentingan suatu korporasi. Sedangkan dalam teori ini, unsur "sekumpulan orang" atau "sekelompok orang" yang bertindak untuk dan atas nama atau bagi kepentingan suatu korporasi menjadi unsur yang penting untuk menganalisir bahwa kesalahan dari sekelompok orang tersebut merupakan atau dapat dikategorikan sebagai kesalahan dari suatu korporasi. ${ }^{24}$

Dengan diterapkannya doktin atau teori ini, dapat mencegah perusahaan atau korporasi menyembunyikan tanggungjawabnya dalam struktur korporasi yang bersangkutan. Dalam kondisi modern seperti sekarang ini, perusahaan atau korporasi modern tidak lagi disusun dalam struktur dan wewenang yang jelas seperti dalam struktur piramida. Sebaliknya, perusahaan-perusahaan modern atau korporasi-korporasi modern memiliki pusat-pusat kekuasaan ganda yang saling berbagi dalam mengendalikan organisasi dan menentukan kebijakannya. ${ }^{25}$

Sama dengan doktrin atau teori vicarious liability atau pertanggungjawaban pengganti, menurut teori atau doktrin ini, lembaga perbankan sebagai suatu korporasi dapat dimintakan pertanggungjawaban secara pidana apabila karyawan atau organ bank melakukan tindak pidana, tindak pidana dilakukan dalam lingkup pekerjaannya dan bank memperoleh manfaat atau keuntungan dari tindak pidana tersebut. Namun demikian, teori ini mensyaratkan kesalahan sejumlah orang secara kolektif sebagai syarat mutlak dalam menjatuhkan pidana bagi korporasi (bank).

\section{f. Reactive Corporate Fault.}

Doktrin keenam yang membenarkan atau menjustifikasi penerapan sistem pertanggungjawaban pidana bagi suatu korporasi adalah doctrine reactive corporate fault. Menurut teori atau doktrin ini, dibawah kesalahan reaktif, perusahaan-perusahaan atau korporasi membuat dirinya sendiri bertanggungjawab

\footnotetext{
${ }^{24}$ Barda Nawawi Arief, Bunga Rampai Kebijakan..., Op. Cit., hlm. 252.

${ }^{25}$ Rise Karmilia, Op. Cit., hlm. 77.
} 
untuk mengamati dan melaporkan disiplin internal setelah sebuah pelanggaran terjadi dan juga menyelesaikan tanggungjawab tersebut. Apabila actus reus (perbuatan) dari tindak pidana terbukti dilakukan oleh atau atas nama suatu korporasi maka pengadilan dapat meminta pertanggungjawaban dari korporasi yang bersangkutan. ${ }^{26}$

Bentuk pertanggungjawaban yang dapat dimintakan terhadap korporasi tersebut antara lain:

a. Meminta korporasi untuk menyelidiki siapa yang bertanggungjawab dalam organisasi korporasi tersebut;

b. Mengambil tindakan disiplin terhadap mereka yang bertanggungjawab;

c. Memerintahkan agar korporasi tersebut mengirimkan laporan yang terperinci mengenai tindakan apa saja yang telah diambil oleh korporasi tersebut dalam menyelesaikan masalah yang bersangkutan.

Menurut teori ini, apabila perusahaan atau suatu korporasi dinilai telah melakukan tindakan yang tepat untuk menyelesaikan masalah tersebut maka pertanggungjawaban pidana tidak akan dikenakan terhadap korporasi yang bersangkutan. Apabila dinilai sebaliknya, dimana korporasi dinilai tidak mengambil tindakan atau langkah-langkah yang cukup dalam rangka menanggulangi tindak pidana tersebut maka korporasi yang bersangkutan dapat dimintakan pertanggungjawaban secara pidana (pertanggungjawaban secara pidana karena telah lalai tidak memenuhi perintah dari pengadilan).

\section{Sistem Pertanggungjawaban Pidana Korporasi \& Sistem Pertanggungjawaban Pidana Korporasi Bagi Bank}

Ketika lembaga perbankan sebagai suatu korporasi dinyatakan bertanggungjawab secara pidana atas tindak pidana yang dilakukan oleh organ atau

${ }^{26}$ Brent Fisse \& John Braithwaite, Corporations, Crime, and Accountability., Cambridge University Press, 1993, pg. 47-49. Lihat juga dalam: Rise Karmilia, Ibid., hlm. 79-80. 
pengurusnya, maka pada umumnya dikenal 3 (tiga) sistem pertanggungjawaban pidana korporasi yaitu sebagai berikut: ${ }^{27}$

1. Pengurus korporasi sebagai pembuat/pelaku tindak pidana dan penguruslah yang harus bertanggungjawab.

Hal ini diterapkan apabila tindak pidana yang dilakukan oleh organ atau pengurus dilakukan secara pribadi. Dalam hal ini maka tindak pidana yang dilakukan oleh organ atau pengurus tidak dilakukan untuk dan atas nama bank, tindak pidana tidak dilakukan dalam lingkup pekerjaannya dan atas tindak pidana tersebut, bank tidak memperoleh manfaat atau keuntungan apapun. Mengingat tindak pidana yang dilakukan bersifat pribadi (bahkan dalam hal ini bank bisa menjadi korban tindak pidana), maka pertanggungjawaban pidananya juga bersifat pribadi kepada pengurus sebagai pelaku tindak pidana. Model pertanggungjawaban pidana ini mendominasi sistem pertanggungjawaban pidana pada Undang-Undang Republik Indonesia Nomor 10 Tahun 1998 Tentang Perubahan Atas Undang-Undang Republik Indonesia Nomor 7 Tahun 1992 Tentang Perbankan. Dikatakan demikian karena pada hakikatnya, ketentuan dan pertanggungjawaban pidana pada Pasal 47 ayat (1), Pasal 47 ayat (2), Pasal 47A, Pasal 48 ayat (1), Pasal 48 ayat (2), Pasal 49 ayat (1) huruf a sampai dengan huruf c, Pasal 49 ayat (2) huruf a dan huruf b, Pasal 50 dan Pasal 50A Undang-Undang Republik Indonesia Nomor 10 Tahun 1998 Tentang Perubahan Atas Undang-Undang Republik Indonesia Nomor 7 Tahun 1992 Tentang Perbankan masih menganut model atau sistem pertanggungjawaban pidana ini.

2. Korporasi sebagai pembuat/pelaku tindak pidana namun penguruslah yang harus bertanggungjawab.

27 Mardjono Reksodiputro, Pertanggungjawaban Pidana Korporasi Dalam Tindak Pidana Korporasi, makalah disampaikan pada Seminar Nasional Kejahatan Korporasi, Fakultas Hukum Universitas Diponegoro (UNDIP), Semarang, tanggal 23-24 November 1989, hlm. 9. 
Dalam hal ini, tindak pidana dilakukan oleh organ atau pengurus, tindak pidana tersebut dilakukan dalam lingkup pekerjaannya, tindak pidana dilakukan ketika pelaku bertindak untuk dan/atau atas nama korporasi (dalam hal ini bank) atau bahkan tindak pidana yang dilakukan memberikan keuntungan atau manfaat bagi bank yang bersangkutan. Namun demikian, ketika terjadi tindak pidana sebagaimana dikemukakan diatas, pertanggungjawaban pidana tidak dapat diterapkan atau dibebankan kepada korporasinya secara langsung melainkan hanya dibebankan kepada organ atau pengurus yang nyata-nyata melakukan tindak pidana tersebut.

Pengaturan sistem pertanggungjawaban pidana korporasi model ini telah diadopsi dalam sistem pertanggungjawaban pidana pada ketentuan pasal 46 ayat (1) dan ayat (2) undang-undang perbankan yang saat ini berlaku yakni Undang-Undang Republik Indonesia Nomor 10 Tahun 1998 Tentang Perubahan Atas Undang-Undang Republik Indonesia Nomor 7 Tahun 1992 Tentang Perbankan.

Ketentuan pasal 46 ayat (1) dan ayat (2) Undang-Undang Republik Indonesia Nomor 10 Tahun 1998 Tentang Perubahan Atas Undang-Undang Republik Indonesia Nomor 7 Tahun 1992 Tentang Perbankan dengan tegas menyatakan bahwa: "Dalam hal kegiatan menghimpun dana dari masyarakat dalam bentuk simpanan tanpa izin usaha dari Pimpinan Bank Indonesia dilakukan oleh badan hukum yang berbentuk perseroan terbatas, perserikatan, yayasan atau koperasi, maka penuntutan terhadap badanbadan dimaksud dilakukan baik terhadap mereka yang memberi perintah melakukan perbuatan itu atau yang bertindak sebagai pimpinan dalam perbuatan itu atau terhadap kedua-duanya".

3. Korporasi sebagai pembuat atau pelaku tindak pidana dan korporasi pula yang harus bertanggungjawab.

Dalam model ini, korporasi dipandang telah menjadi subjek tindak pidana.

Oleh karena itu, korporasi dinilai dapat melakukan tindak pidana dan dapat mempertanggungjawabkan perbuatannya secara pidana. Undang-undang perbankan yang saat ini berlaku yakni Undang-Undang Republik Indonesia 
Nomor 10 Tahun 1998 Tentang Perubahan Atas Undang-Undang Republik Indonesia Nomor 7 Tahun 1992 Tentang Perbankan sama sekali belum menganut atau belum mengadopsi model sistem pertanggungjawaban pidana ini karena dalam Undang-Undang Republik Indonesia Nomor 10 Tahun 1998 Tentang Perubahan Atas Undang-Undang Republik Indonesia Nomor 7 Tahun 1992 Tentang Perbankan, korporasi dipandang tidak dapat melakukan tindak pidana [kecuali ketentuan pasal 46 ayat (1) dan ayat (2)] dan oleh karenanya korporasi (dalam hal ini bank) tidak dapat dipertanggungjawabkan secara pidana (pertanggungjawaban pidana hanya dibebankan kepada pengurus atau organnya).

Terkait dengan hal ini, penulis menilai, jika tindak pidana perbankan yang dilakukan memenuhi syarat-syarat yang ditentukan sebagaima termuat dalam "teori-teori sistem pertanggungjawaban pidana korporasi" tersebut diatas misalnya: dapat diidentifikasi bahwa tindak pidana perbankan dilakukan oleh senior officer atau directing mind, tindak pidana memenuhi rumusan delik sebagaimana dirumuskan dalam undang-undang, tindak pidana dilakukan untuk dan atas nama korporasi, tindak pidana dilakukan oleh organ atau pengurus korporasi dalam lingkup pekerjaannya, tindak pidana itu memberikan keuntungan atau manfaat bagi korporasi, tindak pidana dilakukan karena diperintahkan oleh personil pengendali korporasi yang sah, tindak pidana dilakukan dalam rangka pemenuhan maksud dan tujuan korporasi, tindak pidana dilakukan melalui agen atau pihak yang berhubungan erat dengan korporasi, terdapat kesalahan sejumlah orang secara kolektif atau tindak pidana dilakukan oleh atau hasil kesepakatan dari sekumpulan orang yang ada pada korporasi tersebut, korporasi tidak membentuk budaya atau sistem bekerja, prosedur, disiplin internal atau pengawasan yang dapat meminimalisir dilakukannya tindak pidana, korporasi gagal menindak pelanggaran (tindak pidana) yang terjadi dalam korporasi tersebut dan berbagai hal lainnya maka tindak pidana yang terjadi dapat dikategorikan sebagai tindak pidana yang dilakukan oleh korporasi. 
Oleh karenanya, korporasi harus dinilai dapat melakukan tindak pidana dan harus dapat dimintakan pertanggungjawaban secara pidana pula.

\section{Beberapa Alasan Pembenar Penerapan Sistem Pertanggungjawaban Pidana Korporasi Bagi Lembaga Perbankan}

Menurut hemat penulis, penerapan sistem pertanggungjawaban pidana korporasi bagi lembaga perbankan harus dikaji dengan menggunakan 2 (dua) perspektif. Perspektif yang pertama, penerapan sistem pertanggungjawaban pidana korporasi bagi lembaga perbankan harus ditinjau secara teoritik dan perspektif yang kedua, penerapan sistem pertanggungjawaban pidana korporasi bagi lembaga perbankan harus ditinjau secara yuridis normatif karena memang hal ini masuk dalam ranah hukum khususnya ranah hukum pidana.

Dalam perspektif yang pertama, jika ditinjau secara teoritik, sistem pertanggungjawaban pidana korporasi bagi lembaga perbankan sangat mungkin untuk dilakukan atau diterapkan. Hal ini didasarkan pada beberapa alasan sebagai berikut:

1. Lembaga perbankan dapat dikategorikan sebagai suatu korporasi. Dikatakan demikian karena lembaga perbankan memenuhi definisi dari korporasi dalam hukum pidana yakni kumpulan orang dan/atau harta kekayaan yang terorganisasi, baik merupakan badan hukum maupun bukan badan hukum.

2. Mengingat dalam perkembangan hukum pidana khusus, korporasi telah diatur menjadi subjek tindak pidana dimana korporasi dinilai dapat melakukan tindak pidana dan mempertanggungjawabkan perbuatannya secara pidana, maka timbul urgensi untuk menjadikan korporasi (dalam hal ini lembaga perbankan dan korporasi lainnya) sebagai subjek tindak pidana dalam Undang-Undang Republik Indonesia Nomor 10 Tahun 1998 Tentang Perubahan Atas Undang-Undang Republik Indonesia Nomor 7 Tahun 1992 Tentang Perbankan.

3. Alasan pragmatis, penerapan sistem pertanggungjawaban pidana korporasi bagi lembaga perbankan diperlukan untuk menjaga 
kepercayaan masyarakat terhadap lembaga perbankan, mencegah dilakukannya tindak pidana perbankan oleh organ atau karyawan bank, dan lain sebagainya.

4. Penerapan sistem pertanggungjawaban pidana korporasi bagi lembaga perbankan dapat meningkatkan kehati-hatian bank dan organ-organ atau pengurus-pengurusnya dalam melakukan suatu perbuatan. Hal ini akan berdampak positif bagi bank yang bersangkutan dimana akan berpengaruh pada peningkatan kesehatan bank.

5. Penerapan sistem pertanggungjawaban pidana korporasi bagi lembaga perbankan dapat dipandang sebagai salah satu bentuk perlindungan terhadap konsumen (dalam hal ini masyarakat luas yang menggunakan jasa perbankan dan memercayakan dananya kepada bank).

6. Lembaga perbankan merupakan aktor utama dalam perekonomian nasional sehingga penerapan sistem pertanggungjawaban pidana korporasi bagi bank dapat dipandang sebagai alternatif yang efektif untuk memengaruhi tindakan-tindakan atau perbuatan-perbuatan dari aktor rasional atau pelaku fungsional bank.

7. Dipidananya pengurus saja tidak cukup untuk mengadakan represif (pencegahan) dilakukannya tindak pidana oleh lembaga perbankan sebagai suatu korporasi.

8. Berdasarkan konsep keberlakuan fungsional (functioneel daderschap), tindak pidana perbankan yang dilakukan oleh organ bank dapat dimintakan pertanggungjawaban pidananya kepada bank yang bersangkutan.

9. Apabila bank mendapat keuntungan atau manfaat dari tindak pidana yang dilakukan oleh organnya, maka bank sebagai subjek hukum harus dimintakan pertanggungjawaban secara pidana pula.

10. Melihat dan menelaah doktrin-doktrin atau teori-teori yang menjustifikasi atau membenarkan penerapan sistem pertanggungjawaban pidana korporasi sebagaimana telah dijelaskan diatas, lembaga perbankan sebagai suatu korporasi seharusnya dapat 
dimintakan pertanggungjawaban secara pidana. Hal tersebut dapat diuraikan sebagai berikut:

a. Jika dilihat dari teori identification theory atau teori identifikasi atau dikenal pula dengan direct liability doctrine maka korporasi (dalam hal ini lembaga perbankan) dapat dimintakan pertanggungjawaban secara pidana apabila tindak pidana tersebut dilakukan oleh "pejabat senior" (senior officer) atau dilakukan oleh orang yang merupakan "directing mind" atau pengambil kebijakan (pada umumnya direktur dan manager) dari korporasi yang bersangkutan sehingga perbuatan dari "pejabat senior" (senior officer) atau "directing mind” tersebut diidentifikasi sebagai perbuatan dan kehendak dari korporasi itu sendiri.

b. Jika dilihat dari teori strict liability atau teori pertanggungjawaban ketat menurut undang-undang maka korporasi (dalam hal ini lembaga perbankan) dapat dimintakan pertanggungjawaban secara pidana apabila pelaku tindak pidana melakukan perbuatan pidana (actus reus) sebagaimana dirumuskan dalam undang-undang tanpa mempersoalkan apakah si pelaku mempunyai kesalahan (mens rea) atau tidak.

c. Jika dilihat dari teori vicarious liability doctrine atau teori pertanggungjawaban pengganti, korporasi (dalam hal ini lembaga perbankan) dapat dimintakan pertanggungjawaban secara pidana dengan prinsip employment principle yang menyatakan bahwa majikan (employer) adalah penanggungjawab utama dari perbuatan para pengurus atau karyawannya. Dalam hal ini, majikan (korporasi - bank) adalah pihak utama yang bertanggungjawab terhadap apa yang dilakukan oleh karyawannya selama perbuatan tersebut dilakukan dalam lingkup pekerjaannya. Penerapan vicarious liability doctrine atau teori pertanggungjawaban pengganti ini harus memenuhi beberapa syarat diantaranya sebagai berikut: tindak pidana dilakukan untuk dan atas nama korporasi, tindak pidana 
dilakukan oleh organ atau pengurus korporasi dalam lingkup pekerjaannya, tindak pidana itu memberikan keuntungan atau manfaat bagi korporasi, tindak pidana dilakukan karena diperintahkan oleh personil pengendali korporasi yang sah, tindak pidana dilakukan dalam rangka pemenuhan maksud dan tujuan korporasi dan tindak pidana dilakukan melalui agen atau pihak yang berhubungan erat dengan korporasi.

d. Jika dilihat dari teori the corporate culture model atau company culture theory atau teori budaya korporasi, suatu korporasi yang dalam hal ini adalah lembaga perbankan dapat dimintakan pertanggungjawaban secara pidana manakala budaya dan sistem kerja pada korporasi tersebut membuka peluang untuk dilakukannya tindak pidana oleh organ atau pengurusnya. Dalam dunia perbankan, teori the corporate culture model sesungguhnya telah dikenal dan diatur secara tegas misalnya dalam prinsip kehati-hatian perbankan, pelaksanaan good corporate governance bagi bank umum, managemen resiko bagi lembaga perbankan dan lain sebagainya. Oleh karenanya, jika dikonstruksikan dengan teori ini maka apabila ada lembaga perbankan yang tidak melakukan atau membentuk sistem kerja yang dapat meminimalisir terjadinya tindak pidana, maka korporasi tersebut seharusnya dapat dimintakan pertanggungjawaban secara pidana.

e. Jika dilihat dari doctrin of aggregation atau teori agregasi maka korporasi yang dalam hal ini adalah lembaga perbankan dapat dimintakan pertanggungjawaban secara pidana manakala tindak pidana atau kejahatan dilakukan oleh orang secara kolektif dimana orang-orang tersebut bertindak untuk dan atas nama suatu korporasi atau bertindak untuk kepentingan korporasi yang bersangkutan. Menurut doktrin ini, semua perbuatan dan unsur mental atau sikap batin atau kesalahan (mens rea) dari kumpulan orang tersebut dianggap sebagai dan dilakukan oleh suatu korporasi sehingga 
korporasi tersebut layak dibebankan pertanggungjawaban secara pidana.

f. Jika dilihat dari teori reactive corporate fault, suatu korporasi (dalam hal ini lembaga perbankan) membuat dirinya sendiri bertanggungjawab untuk mengamati dan melaporkan disiplin internal setelah sebuah pelanggaran atau tindak pidana terjadi dan juga menyelesaikan tanggungjawab tersebut. Menurut teori ini, apabila perusahaan atau suatu korporasi (termasuk didalamnya bank) dinilai telah melakukan tindakan yang tepat untuk menyelesaikan masalah tersebut maka pertanggungjawaban pidana tidak akan dikenakan terhadap korporasi yang bersangkutan. Apabila dinilai sebaliknya, dimana korporasi dinilai tidak mengambil tindakan atau langkah yang cukup dalam rangka menanggulangi tindak pidana tersebut maka korporasi yang bersangkutan dapat dimintakan pertanggungjawaban secara pidana.

\section{PENUTUP}

Sistem pertanggungjawaban pidana korporasi ini dilegitimasi dan dijustifikasi oleh beberapa doktrin atau teori yakni: identification theory (teori identifikasi), strict liability theory (teori pertanggungjawaban ketat menurut undang-undang), vicarious liability doctrine (teori atau doktrin pertanggungjawaban pengganti), the corporate culture model atau company culture theory (teori budaya korporasi), doctrin of aggregation (doktrin agregasi) dan reactive corporate fault. Jika dikaitkan dengan pokok permasalahan dalam makalah ini, sistem pertanggungjawaban pidana korporasi sebagaimana dilegitimasi dan dijustifikasi oleh berbagai teori tersebut dapat diterapkan terhadap lembaga perbankan. Dengan demikian, bank dipandang dapat melakukan tindak pidana dan menanggung pertanggungjawaban pidana. Selain itu, pengaturan dan penerapan sistem pertanggungjawaban pidana korporasi bagi lembaga perbankan dapat dibenarkan dengan alasan mendasar diantaranya: dalam perkembangan hukum pidana khusus, korporasi telah diatur menjadi subjek tindak pidana; penerapan 
sistem pertanggungjawaban pidana korporasi bagi lembaga perbankan diperlukan untuk menjaga kepercayaan masyarakat terhadap lembaga perbankan dan memberikan perlindungan terhadap konsumen; mencegah tindak pidana perbankan oleh organ atau karyawan bank; penerapan sistem pertanggungjawaban pidana korporasi bagi lembaga perbankan dapat meningkatkan kehati-hatian bank dalam melakukan suatu perbuatan; pertanggungjawaban pidana korporasi bagi bank dapat dipandang sebagai alternatif yang efektif untuk memengaruhi tindakan atau perbuatan dari aktor rasional atau pelaku fungsional bank; dipidananya pengurus saja tidak cukup untuk mengadakan pencegahan tindak pidana oleh lembaga perbankan sebagai suatu korporasi dan berbagai alasan lainnya.

Namun demikian, sangat disayangkan sistem pertanggungjawaban pidana bagi lembaga perbankan sebagai suatu korporasi belum dapat diterapkan karena Undang-Undang No 7 Tahun 1992 Tentang Perbankan masih didominasi oleh asas "societas delinquere non potest" atau asas "universitas delinquere non potest" yaitu sebuah asas yang menyatakan bahwa badan hukum (lembaga perbankan) tidak dapat melakukan tindak pidana dan oleh karenanya tidak dapat dimintakan pertanggungjawaban secara pidana. Oleh karena itu, wajar jika sistem pertanggungjawaban pidana yang dianut dalam undang-undang ini hanya dapat diterapkan terhadap manusia alamiah. Adapun sistem pertanggungjawaban pidananya adalah "pengurus korporasi sebagai pembuat/pelaku tindak pidana dan penguruslah yang harus bertanggungjawab" dan "korporasi sebagai pembuat/pelaku tindak pidana namun penguruslah yang harus bertanggungjawab" (khusus ketentuan pasal 46 undang-undang perbankan). Selain itu, tidak dapat diterapkannya sistem pertanggungjawaban pidana korporasi bagi lembaga perbankan karena terbentur dengan asas legalitas.

Untuk mengatasi berbagai persoalan yang timbul maka dimasa yang akan datang, Undang-Undang Republik Indonesia Nomor 10 Tahun 1998 Tentang Perubahan atas Undang-Undang Republik Indonesia Nomor 7 Tahun 1992 Tentang Perbankan perlu direvisi dengan memperhatikan beberapa hal sebagai berikut:

1. Sistem pertanggungjawaban pidana korporasi bagi lembaga perbankan perlu diatur secara tegas. 
2. Sistem pertanggungjawaban pidana dalam undang-undang perbankan perlu mengadopsi sistem pertanggungjawaban pidana korporasi yakni: "korporasi dipandang sebagai pembuat atau pelaku tindak pidana dan korporasi pula yang harus bertanggungjawab secara pidana".

3. Sistem pertanggungjawaban pidana dalam undang-undang perbankan juga perlu mengadopsi sistem pertanggungjawaban pidana korporasi bentuk lainnya yakni "pengurus dan korporasi keduanya sebagai pelaku tindak pidana dan keduanya pula yang harus memikul pertanggungjawaban pidana". Hal ini dapat dilakukan dengan mengatur bahwa "Penuntutan dan penjatuhan pidana dapat dilakukan terhadap pengurus dan/atau korporasi".

4. Dalam undang-undang perbankan perlu diatur secara tegas kualifikasi tindak pidana sebagai tindak pidana yang dilakukan oleh bank (kapan dan dalam hal bagaimana suatu tindak pidana yang dilakukan oleh organ atau pengurus atau pegawai atau karyawan bank dipandang sebagai tindak pidana yang dilakukan oleh bank). Dengan cara ini akan tercipta kepastian hukum dan bank sebagai suatu korporasi layak dibebani pertanggungjawaban secara pidana.

5. Perlu dipikirkan lebih lanjut mengenai bentuk sanksi pidana yang cocok diterapkan bagi lembaga perbankan sehingga pidana yang dijatuhkan terhadap suatu bank tidak menimbulkan effect domino atau berdampak sistemik pada bank lainnya. 


\section{DAFTAR PUSTAKA}

\section{A. Buku}

Barda Nawawi Arief, Bunga Rampai Kebijakan Hukum Pidana, Cetakan Ke Dua Edisi Revisi, Bandung, Citra Aditya Bakti, 2002. , Sari Kuliah Perbandingan Hukum Pidana, PT. RajaGrafindo Persada, Jakarta, 2002. , Perbandingan Hukum Pidana, PT Raja Grafindo Persada, Jakarta, 2010.

Brent Fisse \& John Braithwaite, Corporations, Crime, and Accountability., Cambridge University Press, 1993.

C.M.V. Clarkson, Understanding Criminal Law,Second Edition, Sweet \& Maxwell, London, 1998.

Hamzah Hatrik, Asas Pertanggungjwaban Korporasi Dalam Hukum Pidana (Strict Liability dan Vicarious Liability), PT. Raja Grafindo Persada, Jakarta, 1996. Hanafi, Strict Liability dan Vicarious Liability dalam Hukum Pidana, Lembaga Penelitian, Universitas Islam Indonesia, Yogyakarta, 1997.

Henry Campbell Black, Black's Law Dictionary, West Publishing Co., St. Paul, Minnessota, 1990, ed.6.

H.Setiyono, Kejahatan Korporasi Analisis Viktimologi Dan Pertanggungjawaban Korporasi Dalam Hukum Pidana, Malang, Bayumedia Publishing, 2003. Johannes Ibrahim dan Yohanes Hermanto Sirait, Kejahatan Transfer Dana (Evolusi

Dan Modus Kejahatan Melalui Sarana Lembaga Keuangan Bank), PT. Sinar Grafika, Jakarta, 2018.

Kristian, Hukum Pidana Korporasi (Kebijakan Integral Formulasi Pertanggungjawaban Pidana Korporasi di Indonesia), CV. Nuansa Aulia, Bandung, 2014. , Sistem Pertanggungjawaban Pidana Korporasi (Tinjauan Teoritis dan Perbandingan Hukum di Berbagai Negara), PT. Refika Aditama, Bandung, 2016. , Sistem Pertanggungjawaban Pidana Korporasi Ditinjau Dari Berbagai Konvensi Internasional, PT. Refika Aditama, 2017.

Loebby Loqman, Kapita Selekta Tindak Pidana Di Bidang Perekonomian, Jakarta, Datacom, 2002. 
Machteld Boot, Nullum Crimen Sine Lege and the Subject Matter Jurisdiction of The International Criminal Court: Genocide, Crimes Against Humanity, War Crimes, Intersentia, Antwerpen - Oxford - New York, 2001.

Mardjono Reksodiputro, Pertanggungjawaban Pidana Korporasi Dalam Tindak Pidana Korporasi, makalah disampaikan pada Seminar Nasional Kejahatan Korporasi, Fakultas Hukum Universitas Diponegoro (UNDIP), Semarang, tanggal 23-24 November 1989.

Muladi, Penerapan Pertanggungjawaban Pidana Korporasi Dalam Hukum Pidana, Bahan Kuliah Kejahatan Korporasi, Universitas Diponegoro (UNDIP). dan Dwidja Priyatno, Pertanggungjawaban Pidana Korporasi, PT. Prenada Media Group, Jakarta, 2010.

Rise Karmilia, Pengaturan Pertanggungjawaban Pidana Korporasi Pada Ketentuan Pidana Di Luar KUHP, Thesis, Universitas Sumatera Utara (USU), 2009.

Russel Heaton, Criminal Law Textbook, Oxford University Press, London, 2006.

Satjipto Rahardjo, Ilmu Hukum, Citra Aditya Bakti, Bandung, 2000.

Sri Mamudji, et.al., Metode Penulisan dan Penelitian Hukum, Penerbit PT. Alumni, 2005.

Sutan Remi Sjahdeini, Pertanggungjawaban Pidana Korporasi, Grafiti Pers, Jakarta, 2006.

V.S. Khanna, Corporate Liability Standars: When Should Corporation Be Criminality Liabel?, American Criminal Law Review, 2000.

\section{B. Peraturan Perundang-Undangan.}

Undang-Undang Republik Indonesia Nomor 7 Tahun 1992 tentang Perbankan.

Undang-Undang Republik Indonesia Nomor 10 Tahun 1998 tentang Perubahan

Atas Undang-Undang Republik Indonesia Nomor 7 Tahun 1992 tentang Perbankan.

\section{Internet}

Christopher M. Little \& Natasha Savoline, Corporate Criminal Liability in Canada: The Criminalization of Occupational Health \& Safety Offences, 
Filion Wakely Thorup Angeletti (Management Labour Lawyers), diakses dari: www.filion.on.ca/pdf/CML\%202003\%20Paper.pdf.

http://www.hukumonline.com. 